DOI: $10.15290 / \mathrm{bsl} .2019 .14 .12$

\author{
Magdalena Roszczynialska \\ Wydział Filologiczny \\ Uniwersytet Pedagogiczny w Krakowie \\ e-mail: m@roszczynialska.pl \\ ORCID: 0000-0003-2529-5100
}

\title{
Rabka z perspektywy geopoetyki. \\ Na marginesie książki \\ Rabka w literaturze, literaci w Rabce
}

Książka pt. Rabka w literaturze, literaci w Rabce pod redakcją Zofii Budrewicz i Jana Ceklarza wydana w 2018 roku staraniem Stowarzyszenia Kulturowy Gościniec w Rabce-Zdroju ${ }^{1}$ wpisuje się w nurt topograficznie zorientowanego literaturoznawstwa. Ze względu na poszerzenie $\mathrm{w}$ niej pola obserwacji o fakty życia literackiego i ich dokumentalny zapis sytuuje się także w obszarze badań nad mikrohistorią lokalnej kultury. Jak zatem jawi się Rabka, rzeczywista i wyobrażona, zapisana na kartach tej monografii?

Przyjąć trzeba na samym początku, że Rabka (na prawach synekdochy obejmująca także gorczańską okolicę) stanowi miejsce w znaczeniu antropologicznym, to znaczy wyróżniony przez człowieka wycinek przestrzeni² Miejsce takie ma trzy aspekty: lokalizacji (a specific location), formy materialnej (a locale) oraz afektywny (a sense of place). Podział, zaproponowany w 1987 roku przez geografa Johna A. Agnewa w książce Place and Politics, przywołuje autorka Psychologii miejsca, Maria Lewicka ${ }^{3}$. Aspekt lokalizacji oznacza koordynaty przestrzenne, geograficzną lokalizację rozumianą jako punkt w przestrzeni wyznaczony przez współrzędne lub delimitowane

\footnotetext{
1 Rabka w literaturze, literaci w Rabce, red. Z. Budrewicz, J. Ceklarz, Rabka-Zdrój: Stowarzyszenie Kulturowy Gościniec, 2018, ss. 276.

2 Yi-Fu Tuan, Przestrzeń i miejsce, przeł. A. Morawińska, Warszawa 1987.

3 M. Lewicka, Psychologia przestrzeni, Warszawa 2012, s. 31.
} 
jakimiś granicami pole. Aspekt materialny oznacza konkretną formę (lub formy), w jakiej (jakich) miejsce się przejawia. Może być to rzeźba terenu, formy przyrodnicze oraz artefakty - np. układ urbanistyczny, budynki z towarzyszącym im zapleczem kulturowym i społecznym, ponieważ chodzi o formy, z których ludzie korzystają w toku swej codziennej aktywności. Aspekt afektywny to nic innego jak znaczenie miejsca, wynikające z subiektywnego stosunku człowieka do niego, z doświadczania miejsca. Ta ostatnia warstwa miejsca ma, znowu, trzy komponenty: przywiązanie do miejsca (sedno afektu miejsca), jego znajomość (identyfikacja, komponent poznawczy) oraz poczucie wzajemnej, dwukierunkowej zależności (komponent behawioralny $)^{4}$. Ze względu na te różne sposoby pojmowania miejsca spodziewamy się otrzymać podobnie zróżnicowane jego wyobrażenia i ich tekstowe reprezentacje. I rzeczywiście, wymienione aspekty wyznaczają kolejne dominanty rabczańskich geopoetyk (literackich i biograficznych).

Zacznijmy od lokalizacji. Tytuł książki sugeruje, że chodzi o pewną całość sygnowaną określeniem Rabka - jak potocznie mówimy o tym miejscu. Tymczasem część zamieszczonych w monografii tekstów odnosi się raczej do drugiego z członów dwuelementowej nazwy: Rabka-Zdrój, mianowicie kurortu, uzdrowiska bądź letniska. Sposób istnienia Rabki jest dwoisty $^{5}$. Ma to fundamentalne znaczenie dla rozumienia miejsca i rodzaju relacji z nim, która wytwarza się $\mathrm{w}$ odniesieniu do tych dwu traktowanych osobno lub łącznie miejsc. Sanatorium, uzdrowisko, szpital mają przecież status heterotopii, przeciw-miejsc, miejsc paradoksalnych ${ }^{6}$, rzeczywistości alternatywnej (jak w opowiadaniu Brunona Schulza Sanatorium pod klepsy$d r a$, gdzie czas biegnie osobnym torem, deformując przestrzeń, podobnie w klasycznej realizacji literatury sanatoryjnej: Czarodziejskiej górze Thomasa Manna). Inaczej mówiąc, mają status miejsca tranzytywnego, miejsca prze$\mathrm{pływu}^{7}$, wreszcie: nie-miejsca, to znaczy lokalizacji standaryzowanej, niespełniającej antropologicznych kryteriów miejsca, nakierowanej na ruch i wydajność 8 . Z tej właśnie przyczyny, dla kuracjuszy i letników: Antoniego Edwarda Odyńca $^{9}$, Jarosława Iwaszkiewicza, Zofii Żurakowskiej i Haliny Poświatow-

\footnotetext{
4 Tamże, s. 106. Tu szerokie omówienie aspektu afektywnego miejsca.

5 Na tę dwoistość zwróciła uwagę Anna Mlekodaj, Jan Fudala - poeta Gorców i Morza Czarnego, w: Rabka..., s. 253-266.

6 M. Foucault, Inne przestrzenie, przeł. A. Rejniak-Majewska, „Teksty Drugie” 2005, nr 6.

7 M. Castells, Społeczeństwo sieci, przeł. K. Pawluś, i in., Warszawa 2008.

8 M. Augé, Nie-miejsca, przeł. R. Chymkowski, Warszawa 2010.

${ }^{9}$ O jego rabczańskim epizodzie napisał Tadeusz Budrewicz, Poeta i panny. Antoni Edward Odyniec w Rabce, w: Rabka..., s. 25-46.
} 
skiej ${ }^{10}$ nie staje się Rabka miejscem autobiograficznym ${ }^{11}$. W ich doświadczeniu pozostaje otium, miejscem "oderwania się" (Iwaszkiewicz), miejscem teatralizacji siebie - więc sztucznym (Odyniec), „przelotowym” (Poświatowska), a nawet „miejscem zapadłym” (taż), z którym nie nawiązało się pozytywnej relacji. Ową świadomość odmienności tego miejsca, jego odbiegania od reguł, miał Iwaszkiewicz, gdy w jednym z listów złośliwie podkreślał dziwaczność adresu letniska, „Poprzeczna Kościuszki” 12, jako nazwy powodującej swego rodzaju odrealnienie.

Wiadomo, że pisano w Rabce dzieła wybitne (m.in. Iwaszkiewicz Stawe $i$ chwałę). Jednak, mimo potencjału wynikającego ze statusu uzdrowiska, a już szczególnie - leczącego choroby płuc, gruźlicę, mimo wytworzenia się, jak pisze Tadeusz Budrewicz, „subkultury kurortowej”, nie stała się Rabka jakąś polską literacką Czarodziejska góra, literacką przestrzenią dramatu psychomachii, scenerią procesów dojrzewania (indywiduów i zbiorowości). Być może w dużej mierze dlatego, że rozwijające się na terenach polskich kurorty miały znamionować tężyznę narodowo-patriotyczną ${ }^{13}$, a nie chorobliwość, nadpodaż zgonów i utratę sił fizycznych, a przenośnie - wyczerpanie kultury. Na taki literacki obraz nie było zapotrzebowania w okresie autonomii galicyjskiej, a tym bardziej w Drugiej Rzeczpospolitej i w okresie PRL-u. Kwestia ta wymaga szerszych badań. Warto rozważyć naszkicowanie literackiej mapy kurortów polskich, która mogłaby stać się pomocna w dalszym dookreślaniu wspomnianej „subkultury kurortowej” (np. jako formacji modernistycznej).

Specyfika Rabki jako Zdroju, uzdrowiska, tym bardziej - leczącego dzieci, wyznacza istnienie $\mathrm{w}$ nim określonych instytucji życia społecznego. Rzecz jasna, chodzi o szpitale, sanatoria, prewentoria, ale także całą infrastrukturę towarzyszącą, jak kina, teatry, koncerty objazdowe itp., a przede wszystkim placówki edukacyjne, przedszkola, szkoły sanatoryjne (jak gimnazjum męskie dra Jana Wieczorkowskiego). Ten fakt znalazł odzwierciedlenie $\mathrm{w}$ podjętych przez autorów monografii tematach, skupionych na rabczańskiej przestrzeni społecznej, uwarunkowanej właśnie statusem miejscowości uzdrowiskowej.

10 Szczegóły ich pobytów w uzdrowisku odtworzyła Zofia Budrewicz, W cieniu Thanatosa. Zofii Żurakowskiej i Haliny Poświatowskiej pobyty w Rabce, w: Rabka..., s. 129-154.

11 M. Czermińska, Miejsca autobiograficzne. Propozycja w ramach geopoetyki, „Teksty Drugie” 2011, nr 5.

12 Tę kapitalną prawdziwą anegdotę przytacza Anna Czabanowska-Wróbel, Adres: Rabka-Zdrój. Iwaszkiewicz w Rabce, w: Rabka..., s. 87-106.

13 O czym przypomina w szkicu wstępnym Magdalena Sadlik, "Popierajmy polskie uzdrowiska” - pierwsze pótwiecze rabczańskiego kurortu (1864-1918), w: Rabka..., s. 11-24. 
$\mathrm{O}$ ile zapewne nie istnieje literacki obraz rabczańskiej heterotopii kurortowej, o tyle swoista przestrzeń osobna - „własny światek”, jak pisze o tym Krystyna Zabawa - wyłania się w toku prezentacji przez badaczkę okoliczności powstania opowiadań z tomu Wesołe przedszkole Marii Kownackiej $^{14}$. Dla pisarki autentyczne przedszkole rabczańskie „Plastusiowo” stało się terenem eksplorowanym podczas prowadzenia obserwacji uczestniczącej. Przedszkole przekształcono w laboratorium eksperymentu dydaktyczno-literackiego, przestrzeń, którą wypada potraktować jako zamkniętą gestem eksperymentatorki, spreparowaną, nie zaś otwartą na realia lokalne (jak chce K. Zabawa). Do dialektyki gestów „kolonialnego” zawłaszczenia i taktyk oporu jeszcze powrócimy.

Tymczasem przejdźmy do wskazania na drugi z obrazów Rabki - osadzony w materialności, w realiach. Przestrzeń społeczna ma bowiem substrat materialny. Pośród wielu instytucji uzdrowiskowych wyróżnia się szkoła sanatoryjna. Gimnazjum dra Jana Wieczorkowskiego stanowiło ośrodek kształtujący wrażliwość, a może nawet całość formacji tożsamościowej, kolejnego z bohaterów monografii, późniejszego lekarza, Zdzisława Olszewskiego. Zawarł on swoje wspomnienia o latach rabczańskich w tomie Michał od $\mathrm{Cy}$ ganów, w którym m. in. podkreśla rangę doświadczeń szkolnych. Autorka artykułu na jego temat, Maria Sienko, stawia tezę, że mógł on nawiązać emocjonalną relację z miejscem dopiero wtedy, gdy jego rodzina po latach przeprowadzek osiadła na dłużej, w Rabce właśnie ${ }^{15}$. Przypadł ten okres na lata szkolne bohatera szkicu, zatem pośrednikiem w afekcie miejsca okazało się gimnazjum.

We wspomnieniach lekarza, inaczej niż u Kownackiej, placówka edukacyjna stanowi miejsce otwarte. Szkoła sanatoryjna (z internatem), a szerzej - całe środowisko kulturalne uzdrowiska - stanowi społeczny konglomerat. Początkowo inteligencja lokalna przecież nie jest lokalna, lecz napływowa do pierwotnej Rabki-wsi. Także do szkoły uczęszczali synowie tej napływowej elity klasowej i ekonomicznej, uczniowie-kuracjusze, wraz z synami bogatych rabczan, co okazało się wyjątkowo fortunne i wzbogacające zasób kultury nie tylko miejscowej (w szkicach Marii Sienko i Joanny Bercal ${ }^{16}$ pojawiają się obszerne listy nazwisk osób wyróżniających się, a uformowanych właśnie w rabczańskim środowisku szkolnym). Placówka ta, jak i całe uzdrowisko,

\footnotetext{
14 K. Zabawa, Rabczańskie dzieci w „Wesolym przedszkolu” Marii Kownackiej, w: Rabka..., s. $165-182$.

15 M. Sienko, Czuła pamięć ludzi i miejsca. Rabczańskie gimnazjum dra Jana Wieczorkowskiego we wspomnieniach absolwenta - Zdzisław Olszewski Michał od Cyganów, w: Rabka.., s. 107-128.

16 J. Bercal, Kropla światła. Rabka w reportażach Ewy Owsiany, w: Rabka..., s. 183-202.
} 
stanowi strefę kontaktu, w której dochodzi do nasilonej wymiany dóbr kulturowych ${ }^{17}$, do migracji intelektualnych.

Szkoła z internatem, w dodatku ulokowana w miejscu o podwyższonej tranzytywności, sprzyja powstawianiu sieci komunikacyjnych oraz wymianie informacji. Jak uważają badacze zjawisk intelektualnej migracji, miejsce tego rodzaju zagęszcza powiązania, nasila inspiracje i wpływy wzajemne ${ }^{18}$. „Migracyjność" aktywizuje i wyzwala niemożliwe gdzie indziej zasoby twórcze (instruktywnym przykładem wielokierunkowej aktywności twórczej może tu być osoba Artura Ilgnera ${ }^{19}$ ).

Dziedzictwo Rabki-Zdroju jako miejsca spotkań i przepływów może być i jest aktualizowane w szeregu przedsięwzięć kulturalnych opartych o ideę wymiany - jak np. Międzynarodowy Festiwal Literatury Dziecięcej. Niekiedy, w innych jednostkach terytorialnych, posunięcia z zakresu marketingu miejsca wymagają wynajdywania tradycji, typu "Muzeum Gwizdka” w Gwizdałach ${ }^{20}$. Marketing terytorialny w Rabce, dzięki specyfice górskiego uzdrowiska, ma rzeczywiste zasoby, po które może sięgać - obok przyrody gorczańskiej i folkloru, są to subkultura uzdrowiskowa i subkultura dziecięca.

Wartościowe byłoby opracowanie (może w toku kolejnych przedsięwzięć naukowych inicjowanych przez Stowarzyszenie Kulturowy Gościniec?) mapy cyrkulacji kultury. Chodziłoby o zmapowanie sieci wpływów i powiązań pomiędzy - napływowymi, przepływowymi i autochtonicznymi - osobami związanymi z Rabką. W myśl materializmu biograficznego osoby te są faktycznymi nosicielami znaczeń, stanowią „wyspecjalizowaną w ułatwianiu kontaktów grupę "mobilizatorów»" 21 (nieprzypadkowo przecież o pochodzącej z Rabki dziennikarce Ewie Owsiany, notabene córce pedagoga wspomnianego gimnazjum, pisze pracę magisterską Joanna Bercal w ramach seminarium urodzonego w Rabce Walerego Pisarka). Bo nie tylko miejsce odciska się w biografii, także biografie rzutują na miejsca. Prawdopodobnie taka

\footnotetext{
17 S. Greenblatt, Manifest badań nad mobilnością kulturową, przeł. M. Borowski, M. Sugiera, „Didaskalia” 2011, nr 106, s. 47.

18 T. Majewski, A. Rejniak-Majewska, W. Marzec, Migracje intelektualne: paradygmaty teorii i materializm biograficzny, w: Migracje modernizmu. Nowoczesność i uchodźcy, red. T. Majewski, A. Rejniak-Majewska, W. Marzec, Łódź 2014, s. 7-55.

19 W tomie Rabka... poświęcono jego twórczości dwa szkice: Jarosław Ławski, Artur Ilgner, poeta życia i alienacji [s. 219-236] oraz Anna Janicka, Uwagi o obrazie kobiety w Pieśniach triesteńskich Artura Ilgnera [s. 237-254].

20 Stan i zróżnicowanie kultury wsi i małych miast w Polsce. Kanon i rozproszenie, red. I. Bukraba-Rylska, W. J. Burszta, Warszawa 2014.

21 S. Greenblatt, Manifest badań nad mobilnością kulturowa, s. 47.
} 
mapa, obok istniejącego Słownika biograficznego Rabki²2 dobrze przysłuży się lokalnemu regionalizmowi.

W ramach badań nad mobilnością kulturową trzeba ponadto zbadać biografie wykorzenionych (emigrantów, i remigrantów-„„powrotników" ${ }^{23}$ ) oraz zakorzenionych - a dokładniej: reakcje tubylców na kształtowanie się i późniejszy kulturowy prymat (?) napływowej inteligencji uzdrowiskowej.

Innym wymiarem aspektu materialnego Rabki jako uzdrowiska (właściwie sytuuje się on już na pograniczu materialności i behawioralnej realizacji afektu) jest sposób jego doświadczania - zawsze z zewnątrz. O ile Rabka jest umiejscowiona, o tyle Zdrój jest nawiedzany. Co za tym idzie, Rabka-Zdrój stanowi modelowy przykład sytuacji interkulturowej, sytuacji spotkania. Sytuacja taka może prowadzić bądź to do ustalenia struktury dominacji (jak u Kownackiej), bądź to bardziej neutralnej konfrontacji. Kilkoro twórców eksponuje (świadomie lub nie) tendencję miejscowości do „wytwarzania relacji międzyprzestrzennych” (wykorzystuję określenie Katarzyny Wądolny-Tatar ${ }^{24}$ ), a w literackich jej urzeczywistnieniach etnopoetykę. Autorka dydaktycznej powiastki, Helena Darowska, konfrontację letnika Henrysia z biedą wiejską czyni podstawą jego przemiany moralnej25, Janina Barbara Górkiewiczowa wyprawia bohaterów trylogii Spłowiałe lata $\mathrm{w}$ podróż inicjacyjną, przebiegającą od swojskiego (Mucharza) do obcego (Rabki-Zdroju) ${ }^{26}$. Także fenomen osobowości księdza Mieczysława Malińskiego jako duszpasterza i dialogiczny styl jego pisarstwa - co sugeruje Zofia Zarębianka ${ }^{27}$ - mają źródło w swoistym skrzyżowaniu i spotkaniu kultur i osób, cechującym Rabkę.

Na przeciwległym biegunie mieści się doświadczenie emiczne, wynikające $\mathrm{z}$ wewnętrznego usytuowania (choć niekoniecznie autochtonii) doświadczającego podmiotu ${ }^{28}$. Lokalizacja ta, zazwyczaj wskutek ciągłego zamieszki-

22 E. Trybowska, M. Olszowska, Stownik biograficzny Rabki, Rabka-Zdrój-Kraków 2012.

23 Korzystam z terminu Elżbiety Dąbrowicz.

24 K. Wądolny-Tatar, Rabka jako miejsce wyróżnione w trylogii Spłowiałe lata Janiny Barbary Górkiewiczowej, w: Rabka..., s. 73-86.

25 K. Woźniakowski, Wakacje Henrysia - rabczańska powiastka Heleny Darowskiej z 1877 roku, w: Rabka..., s. 47-60.

${ }^{26}$ K. Wądolny-Tatar, Rabka jako miejsce wyróżnione w trylogii Spłowiałe lata Janiny Barbary Górkiewiczowej.

27 Z. Zarębianka, Ksiądz Mieczysław Maliński oraz inni księża-pisarze związani z Rabka, w: Rabka..., s. $153-164$.

28 O epistemologiach umiejscowienia por. E. Domańska, Epistemologia pogranicza, w: Na pograniczach literatury, red. J. Fazan, K. Zajas, Kraków 2012, s. 87 oraz M. Czermińska, Punkt widzenia jako kategoria antropologiczna i narracyjna w prozie niefikcjonalnej, „Teksty Drugie” 2003, nr 2-3. 
wania przez osobę $\mathrm{w}$ danej przestrzeni oraz intensywnego, codziennego jej doświadczania - szczególnie $\mathrm{w}$ praktykach przestrzennych takich, jak chodzenie, wędrowanie, dryf ${ }^{29}$ (gdy idzie o reportera, historyka, antropologa także rozpytywanie) oznacza jednocześnie bliższy i bardziej osobisty kontakt $\mathrm{z}$ miejscem, a nawet identyfikację $\mathrm{z}$ nim $\mathrm{w}$ przypadku tożsamości poszerzonej, włączonej w duchowo rozumianą przyrodę.

Miejsce w aspekcie afektywnym - bo o nim teraz mowa - łączy się z przyjmowaniem przez podmiot postawy auto/bio/geograficznej ${ }^{30}$, uniemożliwiającej przeżywanie siebie $\mathrm{w}$ oderwaniu od parametru przestrzennego. Poetyki afektywne miejsca (topo-grafie afektywne) będą akcentowały przywiązanie do miejsca, wiedzę na jego temat (np. na temat historii miejsca, geografii, botaniki, zoologii, klimatu, etnografii, języka - gwary, rzemiosła, sztuki itd.) oraz zależność podmiotu od miejsca i miejsca od podmiotu.

Objawem przywiązania, a wręcz lojalności wobec miejscowości rodzinnej jest pisarstwo reportażystki Ewy Owsiany, która - jak ujęła to Joanna Bercal - jako dziennikarka „zawsze pozostawała otwarta na współpracę, gdy temat wiązał się z Rabką" (warto zwrócić uwagę także na eksponowaną w artykule „epistemologię umiejscowienia" 31 autorki, która dziennikarstwo definiuje jako obecność, bycie wewnątrz, uczestniczenie) ${ }^{32}$.

Afektualne opisy Rabki, rzecz charakterystyczna, że przeważnie już nie Zdroju, lecz raczej przyrody gorczańskiej, nasycone są w pisarstwie tej autorki, a także w utworach Juliana Kawalca ${ }^{33}$ i Jana Fudalii ${ }^{34}$ szczegółem onomastycznym i toponomastycznym, gwarą, lokalnym nazewnictwem desygnatów w świecie przyrody ożywionej i nieożywionej. Deskrypcja dokonywana jest z uwzględnieniem kategorii lokalnych, wiedzy lokalnej35.

W przypadku dwu ostatnich wymienionych twórców dochodzi - z pomocą tych uszczegółowionych opisów - już nie tylko do identyfikacji terytorium, lecz zarazem do identyfikacji $\mathrm{z}$ terytorium, syntopii (formą czego byłoby chłopskie żywobycie) ${ }^{36}$.

${ }^{29}$ O retoryce przechadzki por. M. de Certeau, Wynaleźć codzienność. Sztuki dziatania, przeł. K. Thiel-Jańczuk, Kraków 2008, Przewodnik dla dryfujących. Antologia sytuacjonistycznych tekstów o mieście, G. Debord i in., przeł. M. Kwaterko, P. Krzaczkowski, Warszawa 2015.

30 E. Rybicka, Geopoetyka. Przestrzeń i miejsce we wspótczesnych teoriach i praktykach literackich, Kraków 2014, s. 277 i nast.

31 Por. przyp. 27.

32 J. Bercal, Kropla światła.

33 B. Faron, Julian Kawalec i Rabka-Zdrój, w: Rabka..., s. 203-218.

34 A. Mlekodaj, Jan Fudala - poeta Gorców i Morza Czarnego.

35 „Wiedza lokalna” jest terminem z domeny antropologii interpretatywnej.

36 O różnych poziomach identyfikacji z krajobrazem por. B. Frydryczak, Krajobraz. Od estetyki the picturesque do doświadczenia topograficznego, Poznań 2013. 
Swoiście utożsamienie to przebiega w przypadku Fudali, który włącza we własną biografię dziedzictwo Władysława Orkana oraz dziedzictwo wołoskiej kultury pasterskiej tym gestem rozszerzając góralszczyznę i rozciągając przestrzennie miejsce swojej przynależności jako przynależności do rozległej, ponadlokalnej wspólnoty kulturowej, nie geograficznej. Tym samym wyzwala lokalną kulturę z roli kultury mniejszości, o tzw. historii pod-

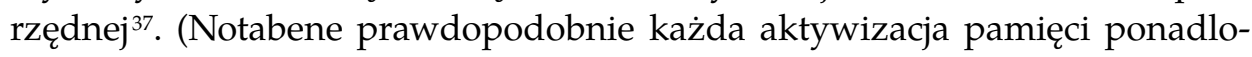
kalnych wspólnot kulturowych, np. żydowskiej, miałaby ten emancypacyjny charakter).

W biografii tego autora można zaobserwować również transakcyjny (behawioralny) aspekt relacji z miejscem: regionalizm nie oznacza bowiem wyłącznie czerpania z zasobów kultury lokalnej lub regionalnej, ale relację zwrotną, uwzględniającą dawanie. $Z$ tego powodu zaafektowani miejscem często podejmują różne role organizacyjne, koncentrujące się na archiwizacji, kultywowaniu i popularyzacji kultury lokalnej. Podobnie odczytywać można gest Ewy Łuskiny, która czerpanie piękna z gorczańskiego krajobrazu równoważy apelem o zaniechanie rabunkowego gospodarowania przyrodą kraju ${ }^{38}$.

Jest to ostatnie zarazem przesłaniem skierowanym (poprzez stulecie) do współczesnych rabczańskich regionalistów. Tożsamość Rabki i Rabki-Zdroju opiera się głównie na ich walorach przyrodniczych i przyrodoleczniczych. Skalanie tego wizerunku opinią jednego z najbardziej zasmogowanych miast w Polsce ugodzi w samą ich istotę, przekształcając - jak głosi jeden $\mathrm{z}$ nagłówków prasowych - „uzdrowiska” w „uśmierciska”.

\section{Bibliografia}

Augé Marc (2010), Nie-miejsca, przeł. R. Chymkowski, Warszawa: Wydawnictwo Naukowe PWN.

Bercal Joanna (2018), Kropla światła. Rabka w reportażach Ewy Owsiany, w: Rabka w literaturze, literaci w Rabce, red. Z. Budrewicz, J. Ceklarz, Rabka-Zdrój: Stowarzyszenie Kulturowy Gościniec, s. 183-202.

Budrewicz Tadeusz (2018), Poeta i panny. Antoni Edward Odyniec w Rabce, w: Rabka w literaturze, literaci w Rabce, red. Z. Budrewicz, J. Ceklarz, Rabka-Zdrój: Stowarzyszenie Kulturowy Gościniec, s. 25-46.

37 D. Chakrabarty, Historie mniejszości, przeszłości podrzędne, przeł. E. Domańska, w: Teorie wiedzy o przeszłości na tle wspótczesnej humanistyki, red. E. Domańska, Poznań 2010, s. 397.

38 M. Skucha, Ekologia i literatura - Rabka i Kraków. Przypadek Ewy Euskiny, w: Rabka..., s. 61-72. 
Budrewicz Zofia (2018), W cieniu Thanatosa. Zofii Żurakowskiej i Haliny Poświatowskiej pobyty $w$ Rabce, w: Rabka w literaturze, literaci $w$ Rabce, red. Z. Budrewicz, J. Ceklarz, Rabka-Zdrój: Stowarzyszenie Kulturowy Gościniec, s. 129-154.

Castells Manuel (2008), Społeczeństwo sieci, przeł. K. Pawluś, i in., Warszawa: Wydawnictwo Naukowe PWN.

Certeau Michel de (2008), Wynaleźć codzienność. Sztuki działania, przeł. K. Thiel-Jańczuk, Kraków: Wydawnictwo UJ.

Chakrabarty Dipesh (2010), Historie mniejszości, przeszłości podrzędne, przeł. E. Domańska, w: Teorie wiedzy o przeszłości na tle wspótczesnej humanistyki, red. E. Domańska, Poznań: Wydawnictwo Poznańskie.

Czabanowska-Wróbel Anna (2018), Adres: Rabka-Zdrój. Iwaszkiewicz w Rabce, w: Rabka w literaturze, literaci w Rabce, red. Z. Budrewicz, J. Ceklarz, Rabka-Zdrój: Stowarzyszenie Kulturowy Gościniec, s. 87-106.

Czermińska Małgorzata (2003), Punkt widzenia jako kategoria antropologiczna i narracyjna w prozie niefikcjonalnej, "Teksty Drugie”, nr 2-3, s. 11-27.

Czermińska Małgorzata (2011), Miejsca autobiograficzne. Propozycja w ramach geopoetyki, „Teksty Drugie”, nr 5, s. 183-200.

Debord Guy i in. (2015), Przewodnik dla dryfujacych. Antologia sytuacjonistycznych tekstów o mieście, przeł. M. Kwaterko, P. Krzaczkowski, Warszawa: Fundacja Bęc Zmiana, 2015.

Domańska Ewa (2012), Epistemologia pogranicza, w: Na pograniczach literatury, red. J. Fazan, K. Zajas, Kraków: Universitas.

Faron Bolesław (2018), Julian Kawalec i Rabka-Zdrój, w: Rabka w literaturze, literaci w Rabce, red. Z. Budrewicz, J. Ceklarz, Rabka-Zdrój: Stowarzyszenie Kulturowy Gościniec, s. 203-218.

Foucault Michel (2005), Inne przestrzenie, przeł. A. Rejniak-Majewska, „Teksty Drugie”, nr 6, s. 117-125.

Frydryczak Beata (2013), Krajobraz. Od estetyki the picturesque do doświadczenia topograficznego, Poznań: Wydawnictwo Poznańskiego Towarzystwa Przyjaciół Nauk.

Greenblatt Stephen (2011), Manifest badań nad mobilnościq kulturowa, przeł. M. Borowski, M. Sugiera, „Didaskalia”, nr 106, s. 47.

Janicka Anna (2018), Uwagi o obrazie kobiety w Pieśniach triesteńskich Artura Ilgnera, w: Rabka w literaturze, literaci w Rabce, red. Z. Budrewicz, J. Ceklarz, Rabka-Zdrój: Stowarzyszenie Kulturowy Gościniec, s. 237-254.

Lewicka Maria (2012), Psychologia miejsca, Warszawa: Wydawnictwo Naukowe Scholar.

Ławski Jarosław, Artur Ilgner, poeta życia $i$ alienacji, w: Rabka w literaturze, literaci w Rabce, red. Z. Budrewicz, J. Ceklarz, Stowarzyszenie Kulturowy Gościniec, Rabka-Zdrój 2018, s. 219-236.

Majewski Tomasz, Rejniak-Majewska Agnieszka, Marzec Wiktor (2014), Migracje intelektualne: paradygmaty teorii i materializm biograficzny, w: Migracje modernizmu. Nowoczesność i uchodźcy, red. T. Majewski, A. Rejniak-Majewska, W. Marzec, Łódź: Łódzkie Stowarzyszenie Inicjatyw Miejskich Topografie, Narodowe Centrum Kultury, s. 7-55. 
Mlekodaj Anna (2018), Jan Fudala - poeta Gorców i Morza Czarnego, w: Rabka w literaturze, literaci w Rabce, red. Z. Budrewicz, J. Ceklarz, Rabka-Zdrój: Stowarzyszenie Kulturowy Gościniec, s. 253-266.

Rybicka Elżbieta (2014), Geopoetyka. Przestrzeń i miejsce we współczesnych teoriach i praktykach literackich, Kraków: Universitas.

Sadlik Magdalena (2018), "Popierajmy polskie uzdrowiska” - pierwsze pótwiecze rabczańskiego kurortu (1864-1918), w: Rabka w literaturze, literaci w Rabce, red. Z. Budrewicz, J. Ceklarz, Rabka-Zdrój: Stowarzyszenie Kulturowy Gościniec, s. 11-24.

Sienko Maria (2018), Czuła pamięć ludzi i miejsca. Rabczańskie gimnazjum dra Jana Wieczorkowskiego we wspomnieniach absolwenta - Zdzisław Olszewski Michał od Cyganów, w: Rabka w literaturze, literaci w Rabce, red. Z. Budrewicz, J. Ceklarz, Rabka-Zdrój: Stowarzyszenie Kulturowy Gościniec, s. 107-128.

Skucha Mateusz (2018), Ekologia i literatura - Rabka i Kraków. Przypadek Ewy Łuskiny, w: Rabka w literaturze, literaci w Rabce, red. Z. Budrewicz, J. Ceklarz, Rabka-Zdrój: Stowarzyszenie Kulturowy Gościniec, s. 61-72.

Stan i zróżnicowanie kultury wsi i małych miast w Polsce. Kanon i rozproszenie (2014), red. I. Bukraba-Rylska, W. J. Burszta, Warszawa: NCK.

Trybowska Elfryda, Olszowska Maria (2012), Słownik biograficzny Rabki, Rabka-Zdrój-Kraków: Oficyna Wydawnicza „Wierchy” Centralnego Ośrodka Turystyki Górskiej PTTK.

Tuan Yi-Fu (1987), Przestrzeń i miejsce, przeł. A. Morawińska, Warszawa: PIW.

Wądolny-Tatar Katarzyna (2018), Rabka jako miejsce wyróżnione w trylogii Spłowiałe lata Janiny Barbary Górkiewiczowej, w: Rabka w literaturze, literaci w Rabce, red. Z. Budrewicz, J. Ceklarz, Rabka-Zdrój: Stowarzyszenie Kulturowy Gościniec, s. 73-86.

Woźniakowski Krzysztof (2018), Wakacje Henrysia - rabczańska powiastka Heleny Darowskiej z 1877 roku, w: Rabka w literaturze, literaci w Rabce, red. Z. Budrewicz, J. Ceklarz, Rabka-Zdrój: Stowarzyszenie Kulturowy Gościniec, s. 47-60.

Zabawa Krystyna (2018), Rabczańskie dzieci w „Wesołym przedszkolu” Marii Kownackiej, w: Rabka w literaturze, literaci w Rabce, red. Z. Budrewicz, J. Ceklarz, Rabka-Zdrój: Stowarzyszenie Kulturowy Gościniec, s. 165-182.

Zarębianka Zofia (2018), Ksiądz Mieczysław Maliński oraz inni księża-pisarze zwiąani z Rabka, w: Rabka w literaturze, literaci w Rabce, red. Z. Budrewicz, J. Ceklarz, Rabka-Zdrój: Stowarzyszenie Kulturowy Gościniec, s. 153-164.

\section{Rabka in Geopoetic Perspective: Discussions Revolving around the Book Rabka w literaturze, literaci w Rabce}

Abstract

The article provides a commentary of the monograph Rabka w literaturze, literaci w Rabce (Rabka 2018) edited on Zofia Budrewicz and Jan Ceklarz mainly in the context of anthropology of place and local microhistory. The 
author seeks to organize the geopoetic studies concerning Rabka, including affects, locality and material dimension of the place. She also points to the duality of the resort town of Rabka-Zdrój, seeing it as the space for intercultural encounters. Finally, she proposes Rabka's cultural map and the Polish literary map of resort subculture.

Keywords: Rabka, literature, geopoetics, psychology of place, standpoint epistemology 